i Kungälv (1985-88), der fremsætter tanken. Men han har også været forstander for en dansk folkehøjskole.

Som sagt: man kan ikke nøjes med at læse denne anmeldelse. Man må læse hele bogen, hvis man vil vide, hvad det grundtvigske betyder i dag, og hvad forholdet mellem folk og kirke er.

\title{
Canada og Grundtvig
}

\section{Af Dorte Thirslund}

K. E. Bugge: Canada og Grundtvig. Nornesalen og Kroghs Forlag A/S 1997. 168 sider. Pris?

Med titlen Canada og Grundtvig har K. E. Bugge ønsket at pege på det forhold, at selv om Grundtvig øjensynlig ikke har beskæftiget sig med Canada i sine skrifter, har Canada i dette århundrede taget Grundtvigs skoletanker til sig; bogen handler om hvordan og $\mathrm{i}$ hvilket omfang, det er sket. Den indgår i en serie af publikationer, hvis formål det er at kortlagge udbredelsen af N.F.S. Grundtvigs højskoletanker til lande uden for Skandinavien. Tidligere er Grundtvigs skoletanker i Japan, Filippinerne og Israel og Grundtvigs skoletanker i USA, Argentina og Chile, begge af Lilian Zøllner, udkommet. Omslaget er Nornesalens velkendte blå himmel under et verdenskort med et sortfarvet Canada. I areal en vældig landvinding på kortet over Verden og Grundtvig.

K. E. Bugge, hvis indsigt i Grundtvigs Skoletanker vil være læsere af Grundtvig Studier bekendt, afslører beskedent i indledningen endnu en usædvanlig forudsætning for at skrive denne bog: ..mine tanker [går] i taknemmelighed til selve det store og smukke land, der under anden verdenskrig tog venligt imod mig, og hvor jeg under trygge og gode forhold gik $i$ skole $i$ fire år. Undersøgelsen af den canadiske Grundtviginspiration bygger da heller ikke alene på et omfattende og mangeartet skriftligt kildemateriale, bogens forudsætning er også 14 interviews med pionerer og nøglepersoner under to studierejser i 1995 og 96.

Bogens første kapitel omhandler de højskoler, som er oprettet af danske immigranter. Det drejer sig om fem folkehøjskoler med de påfaldende navne Dalum, Dana, Danebod, Dannevang og Danebyrd. De har bl.a. det til fælles, at de generelt har undervist på dansk, og at de fik en meget kort virketid. Den ældste er fra 1921, og alle måtte de lukke før 1935 pga. depressionen. Forskellige tiltag efter krigen på oprindeligt dansk initiativ behandles også i dette afsnit.

Herpå følger bogens hovedemne, den hjemmegroede, canadiske voksenundervisningsbevagelse og dens inspiration fra Grundtvig, beskrevet i fire kapitler svarende til en opdeling af landet i fire regioner. K. E. Bugge redegør indledningsvis for hvert af områdernes erhvervsøkonomiske og kulturelle særpræg og knytter disse forhold sammen med opkomsten af netop den type voksenundervisning, som udvikler sig i regionen.

»The Antigonish Movement « har navn efter en lille by i Nova Scotia, hvor en folkelig voksenundervisning i begyndelsen af 20 -erne, med efterfølgende oprettelse af forskellige kooperative virksomheder, vendte en $\emptyset$ konomisk nedgang for den i forvejen 
håbløst fattige lokalbefolkning til erhvervsmæssig fremgang og skabte optimisme og interesse for mere oplysning. K. E. Bugge påviser her bl. a. et interessant eksempel på en Grundtvigsk inspiration, som udelukkende er kommet til Canada gennem samtale og fortælling fra menneske til menneske, helt i Grundtvigs egen ånd. Det er historien om tre fætre, alle katolske præster. De to, James Tompkins og Moses Michael Coady, var ordinerede og videreuddannede i Rom, og efter hjemkomsten blev de begge oprigtigt optagede af spørgsmålet om, hvordan man kunne afhjælpe den dybe sociale nød på Nova Scotia. Netop som deres overvejelser var godt i gang, kom deres slægtning Miles Tompkins hjem fra Europa og fortalte begejstret om, hvad han havde set i Danmark. Tompkins havde været feltpræst under krigen og havde inden hjemrejsen bes $ø$ gt flere europæiske lande i studieøjemed, idet han havde en landbrugsvidenskabelig uddannelse og til daglig var leder af et mønsterbrug. I Danmark havde han personligt stiftet bekendtskab med højskolebevægelsen og andelsbevægelsen. Hans fortælling fik M. M. Coady til at udbryde: Her er jeg, med to doktorgrader fra Rom og en magistergrad fra Washington. Ved Gud, jeg burde vare $i$ stand til at gøre noget positivt og progressivt for bønderne i dette land. Coady så formentlig her sig selv i rollen som en ny Bishop Grundtvig, som han kaldes med de ord, der falder mest naturligt i det kirkeligt orienterede Canada. I 1921 udgav James Tompkins The Antigonish Movement's første skrift, Knowledge for the People, og i 30-erne fulgte Coady's flere gange trykte Masters of their own Destiny.

Bogen fortsætter med Den centrale Region - med scerligt henblik på Ontario, Prarieprovinserne og Stillehavsregionen. I redegørelsen kommer K. E. Bugge både ind på ældre og nye tiltag i voksenundervisningen, herunder på grene af voksenundervisningsbevægelsen, som $f ø r s t$ på et senere stadium af udviklingen [opdager] at de har ikke så lidt til falles med den danske tradition.

Der er en slående modsætning mellem det forhold, at det er af afgørende betydning for Grundtvigforskningen at få klarlagt udbredelsen af, hvor og hvordan Grundtvig har inspireret resten af verden og målgruppen for denne bog. Talmæssigt er der sikkert kun få, som umiddelbart kan have interesse i emnet. Til gengæld er de godt hjulpet. Bogen er skrevet med danske læsere for $\emptyset j$ je og de indledende forklaringer, oversættelser af engelsksprogede citater og bogens hele fremstillingsform gør den let tilgængelig for enhver. Enkelte vil måske savne et register. Bogen er både folkelig og spændende og det oplyses, at en engelsk udgave er under udarbejdelse. 